\title{
Immunomodulatory Effect of Irradiated $\beta$-glucan in Diethylnitrosamine Induced Renal Toxicity
}

\author{
Gehan R. Abdel-Hamed ${ }^{(1) \#}$, Lobna A. Abdel-Aziz ${ }^{(2)}$ and Lobna M. Anees ${ }^{(2)}$ \\ ${ }^{(1)}$ Radiation Biology Department, National Center for Radiation Research and \\ Technology (NCRRT), Atomic Energy Authority (AEA), Cairo, Egypt; (2) Health \\ Radiation Research Department, National Center for Radiation Research and \\ Technology (NCRRT), Atomic Energy Authority (AEA), Cairo, Egypt.
}

\begin{abstract}
$\mathbf{R}_{\text {-GLUCANS are one of the most abundant forms of polysaccharides known as biological }}$ response modifiers which influence host's biological response and stimulate immune system. Accordingly, this study is carried out to evaluate the effect of gamma irradiated $\beta$-glucan (I $\beta$ glucan) extracted from mushroom in modulating diethylnitrosamine (DEN)-induced immune response and mitochondrial dysfunction in renal toxicity. Rats were divided into 4 groups. Group I: control group, group II: animals received the DEN $(20 \mathrm{mg} / \mathrm{kg})$ for 6 weeks, group III: was gavaged I $\beta$-glucan $(65 \mathrm{mg} / \mathrm{kg}$ b. wt.) for 6 weeks, group IV: received as group II and then treated as group III. Exposure to DEN induced a change in the levels of cytokines (IFN- $\gamma$, TNF- $\alpha$, IL6) and nephrotoxicity, which was proved by significant elevated levels of creatinine and urea along with upregulation of mRNA cytochrome P450 (2E1) and downregulation in mitochondrial enzymes complex I and II. Treatment with I $\beta$-glucans post DEN-exposure significantly improved the disturbances in all the ++ tested parameters. It could be concluded that I $\beta$-glucan treatment exerts a potential biological effect on both mitochondrial and immune system dysfunction caused by the DEN- induced renal toxicity in rats. It is considered for further trials.
\end{abstract}

Keywords: I $\beta$-glucan, DEN, Cytokines, Cytochrome P450 (2E1), Mitochondrial complexes.

\section{Introduction}

One of the naturally occurring polysaccharides is $\beta$-glucans (glucose polymers) and it is produced by a variety of plants, such as oat, barley, and mushroom. $\beta$-glucan is a strong immune stimulant and antagonist to both benign and malignant tumors. Also, it diminished the levels of cholesterol and triglycerides and normalizes blood sugar level (Sima et al., 2018). $\beta$-glucan could modify the biological response that can regulate the immune system by stimulating phagocytosis which is followed by the production of pro and anti -inflammatory cytokines (Vetvicka, 2011; Silveira et al., 2014; Ruthes et al., 2013 and Smeekens et al., 2015). Moreover, $\beta$-glucan is a non-toxic to the cells of the host organism by empowering the defense mechanisms of the host against disease instead of attacking the infectious agent leading to lack of any toxic or adverse effects (Zeković et al., 2005 and Sener et al., 2005). Also, beta-glucans can bind directly to specific receptors of immune cells (Vos et al., 2007).
Because of its polymeric structure, $\beta$-glucan has antioxidant and free radical scavenger properties, which is the most important mechanism proposed for the protective effects of $\beta$-glucan (Jaehrig et al., 2007). In this investigation, $\beta$-glucan was exposed to $50 \mathrm{kGy}$ to enhance the potential of its solubility and viscosity without changes in the functional group status as per El-Sonbaty et al. (2013), who found that both non-irradiated and irradiated $\beta$-glucan (I $\beta$-glucan) had a similar pattern of FTIR spectra. In addition, ionizing radiation leads to the degradation of polysaccharides such as starch, cellulose, and pectin by the cleavage of the glycosidic bonds (Cho et al., 2003).

One of the imperative groups of carcinogens is nitroso compounds which frequently present in human environment and food preservation. Nitroso compounds could be converted to nitrosamine due to the effect of heat and gastric acid, also produced from metabolism of some drugs (Verna et al., 1996). Under a certain condition such as acidic $\mathrm{pH}$ of the stomach, 
nitrosamine is formed endogenously from nitrate (Jakszyn \& Gonzalez, 2006). It was reported that diethylnitrosamine (DEN) causes oxidative stress during the metabolism that prompts cytotoxicity, mutagenicity and carcinogenicity (Pradeep et al., 2007 and Farombi et al., 2009). By the action cytochrome $\mathrm{p}_{450}$ enzymes, DEN activated metabolically to produce reactive electrophiles that increase the level of oxidative stress and cell injury (Ezz et al., 2017). The cell injury induced by DEN was achieved through its metabolized end product (ethyl radical), which induces DNA damage that plays a role in carcinogenesis (Bansal et al., 2000).

The mitochondrial respiratory enzyme activities (electron transport chain) comprise 5 complexes: NADH-ubiquinone reductase (complex I), succinate-Q reductase (complex II), cytochrome c oxidoreductase (complex III), cytochrome c oxidase (complex IV) and ATP synthase (complex V). The protons are moving into the inter membrane space and combinate with substrates of the Complexes I, III and IV, creating the gradient that drives ATP synthase (complex V) (Fulda et al., 2010). Cellular energy was generated by the process of oxidative phosphorylation (OXPHOS) in the mitochondrial cell as adenosine triphosphate (ATP), which contains hundreds of them (Andersson et al., 1998). Complex I is the largest of the five enzyme super complexes in the mitochondrial electron transport chain. In spite of the fact that complex I plays an initial step of the oxidative phosphorylation pathway, it is not understood partly because of the number of its sub-units and their potential collaborations (Perfeito et al., 2012).

The more important aspects of mitochondrial OXPHOS for disease pathogenesis are: (i) energy production, (ii) generation of reactive oxygen species (ROS). (ii) Modulation of programmed cell death (apoptosis). OXPHOS proteins incorporate the electron transport chain (ETC) components; The ETC oxidizes hydrogen derived from the oxidation of organic acids for example, pyruvate and fatty acids with atomic oxygen to generate water (Shoffiner \& Wallace, 1995). Hence, the main objective of this study is to evaluate the immunomodulatory effect of the irradiated $\beta$-glucan on DEN-induced renal impairment.

\section{Materials and Methods}

Chemical

Diethylnitrosamine was purchased from Sigma Aldrich's. Louis, Mo. USA.

Extraction of $\beta$-glucan

$\beta$-glucan was extracted from edible mushroom Agaricus bisporus fungi according to the method published by Hunter et al. ( 2002).

\section{$\beta$-D-glucan irradiation}

$\beta$-glucan powder was exposed to a single dose of $\gamma$-radiation ( $50 \mathrm{KGy}$ ) at room temperature (25 \pm $2^{\circ} \mathrm{C}$ ) performed by $\mathrm{Co}^{60}$ gamma cell-40 at a dose rate of $10 \mathrm{k} \mathrm{Gy} /$ hour at the National Center for Radiation Research and Technology (NCRRT), Atomic Energy Authority, Cairo, Egypt. The irradiated $\beta$-glucan sample was stored at $4^{\circ} \mathrm{C}(\mathrm{El}-$ Sonbaty et al., 2013).

\section{Experimental animals}

The animals were housed in plastic cages, kept under normal temperature, pressure, humidity, good ventilation and illumination conditions. Rats were supplied with water and standard granular chowed and libitum and handled according to the rules and regulations of the National Centre of Radiation Research and Technology (NCRRT) Committee for Experimental Animals.

\section{Experimental design}

40 Male Swiss albino rats were categorized into four main groups as follows: Group I: normal control. Group $\Pi$ : rats received DEN $(20 \mathrm{mg} / \mathrm{kg}$ b.wt.) five times per week for 6 weeks orally. Group III: animals were given I $\beta$-glucan $(65 \mathrm{mg} /$ $\mathrm{kg}$ b.wt. daily) for 6 weeks. Group IV: animals received the same treatment as group II and then treated with I $\beta$-glucan as group III.

\section{Blood and tissue sampling}

All animals were anesthesized with ether after $24 \mathrm{~h}$ of the last treatment. Blood samples were withdrawn by heart puncture, using heparinized syringes. Blood was centrifuged and the separated plasma was used for the investigations. Kidney was excised and frozen in liquid nitrogen and stored at $-80^{\circ} \mathrm{C}$ until being used.

Determination of urea and creatinine levels in serum

Levels of urea and creatinine were determined colorimetrically using commercially available 
kits (Bioclin, Santacoloma, Spain).

Determination of cytokines levels tumor necrosis factor- $\alpha(T N F-\alpha)$, interleukin-6 levels (IL-6) and interferon-gamma (INF- $\gamma)$

Plasma was used for the determination of TNF- $\alpha$, IL- 6 and INF- $\gamma$ using ELISA kits for rat (Glory Science Co., Ltd., USA). The measurements were performed according to the catalog instruction guidelines.

Detection of mitochondrial enzymes in renal tissue homogenate

Isolation of mitochondria

kidney samples were homogenized and minced in ice-cold extraction buffer $(250 \mathrm{mM}$ sucrose,20mM Hepes, $10 \mathrm{mM} \mathrm{KCl,1.5mM} \mathrm{MgCl} 2$ ,1mM EDTA,1mM EGTA, 1mM DTT and 0.1 $\mathrm{mM}$ phenylmethylsulphonyl fluoride, $\mathrm{pH}$ 7.4) in the presence of the protease inhibitor cocktail. Following a gentle homogenization with a Teflon pestle motorized with an electronic stirrer, homogenates were centrifuged at $800 \mathrm{~g}$ for $10 \mathrm{~min}$ at $4^{\circ} \mathrm{C}$ to pellet the nuclei and cell debris. The supernatants were then spun twice at $16000 \mathrm{~g}$ for $20 \mathrm{~min}$ at $4{ }^{\circ} \mathrm{C}$ to pellet the mitochondria, and the final supernatants were collected as nuclei-free, mitochondria-free cytosolic protein fractions (Sui et al., 2004).

\section{RNA extraction and $c D N A$ synthesis}

To investigate the changes in mRNA expressions of $\mathrm{CYP}_{4502 \mathrm{El}}$, complex I (NADHubiquinone reductase), and complex II (succinateubiquinone oxidoreductase), total RNA was isolated from $100 \mathrm{mg}$ kidney using TRIzol reagent
(Life Technologies, USA) in accordance to the manufacturer's instructions. RNA integrity was confirmed by $1 \%$ agarose gel electrophoresis and stained with ethidium bromide. First strand complementary DNA (cDNA) synthesis was performed by reverse transcriptase (Invitrogen) according to the manufacturer's protocol using $1 \mu \mathrm{g}$ of total RNA as the template.

\section{Quantitative real time $P C R$}

qRT-PCR was performed using an optical 96-well plate with an ABI PRISM 7500 fast sequence detection system (Applied Biosystems, Carlsbad, California) and universal thermal cycling conditions $\left(95^{\circ} \mathrm{C}\right.$ for $10 \mathrm{~min}, 40$ cycles of $95^{\circ} \mathrm{C}$ for $15 \mathrm{sec}$ and $60^{\circ} \mathrm{C}$ for $\left.60 \mathrm{sec}\right)$. Each $10 \mu 1$ reaction contained $5 \mu \mathrm{l}$ SYBR Green Master Mix (Applied Biosystems), 0.3 $\mu$ l gene specific forward and reverse primers $(10 \mu \mathrm{M}), 2.5 \mu \mathrm{cDNA}$ and $1.9 \mu \mathrm{l}$ nuclease-free water. The sequences of PCR primer pairs used for each gene are shown in Table 1.

\section{Gel electrophoresis}

Ten $\mu$ of PCR product was analyzed on $2 \%$ agarose gel with ethidium bromide staining and the product was visualized on ultraviolet transilluminator, then gel documentation was performed. PCR products were semi-quantified using a gel documentation system (Bio Doc Analyze) supplied by Biometra, Germany. The relative expression of the studied genes was calculated using the comparative threshold cycle method. All values were normalized to the GAPDH genes (Kushnareva et al., 2002).

TABLE 1. Primer sequences used for RT-PCR .

Gene

Cytochrom

$\mathrm{P}_{450}(\mathrm{E} 1)$

NADH: ubiquinone

oxidoreductase (Complex I)

Succinate Dehydrogenase

(Complex II)

$\beta$-actin

Primer sequence

GenBank accession No.

F: 5'-ATGGATGCTGTGGTGCATGA-3'

R: 5'CTCTGGTTGCTTCATGGGGT-3'

F: 5'- CACTGGTGGATTGTCCCTCC -3'

R: 5'- AGAAGCTTGTGTGCATCCGA -3'

F: 5'- GCCATGAACATCAACGGAGG-3'

R: 5'- GGTCCTCGATGGATTGCAGA- 3'

F: 5'TGTTGTCCCTGTATGCCTCT-3'

R: 5'TAATGTCACGCACGATTTCC-3' $\geq \underline{\mathrm{NM}} \mathbf{0 3 1 5 4 3 . 1}$

$>$ NM_001106426.1

$>\underline{\mathrm{NM} 001100539.1}$ 


\section{Determination of DNA fragmentation}

For determination of genomic DNA fragmentation, rat kidney was rapidly removed, washed of blood, frozen in liquid nitrogen, and ground to powder. The powdered tissue was transferred to a 50-ml centrifuge tube with extraction buffer $(10 \mathrm{mmol} / \mathrm{L}$ tris- $\mathrm{HCl}[\mathrm{pH} 8.0]$, $0.1 \mathrm{~mol} / \mathrm{L}$ EDTA $[\mathrm{pH} 8.0]$ and $0.5 \%$ SDS, was first incubated for $1 \mathrm{~h}$ at room temperature and then digested in the same buffer with $200 \mu \mathrm{g} / \mathrm{ml}$ proteinase $\mathrm{K}$ (Sigma) at $50^{\circ} \mathrm{C}$ overnight. An equal volume of phenol equilibrated with $1 \mathrm{~mol} / \mathrm{L}$ tris buffer ( $\mathrm{pH}$ 8.0) was then added, and the tube was placed on a roller apparatus for 1 hour. After the two phases were separated by centrifugation at $5000 \mathrm{~g}$ for $30 \mathrm{~min}$ at room temperature, the viscous aqueous phase was transferred to a clean $50-\mathrm{ml}$ tube, and the extraction was repeated with an equal volume of phenol/chloroform. After the second extraction, the aqueous phase was transferred to a new $50-\mathrm{ml}$ tube and the DNA precipitated by addition of $0.1 \mathrm{vol} 3 \mathrm{~mol} / \mathrm{L}$ sodium acetate and 2 vol $100 \%$ ethanol. DNA precipitate was collected by centrifugation at $5000 \mathrm{~g}$ for $20 \mathrm{~min}$ at room temperature, rinsed with $70 \%$ ethanol, and finally resuspended in $0.5 \mathrm{ml}$ extraction buffer in a 1.5 $\mathrm{ml}$ micro centrifuge tube until dissolved. The concentration of DNA in each sample was measured using spectrophotometry (260nm). To detect DNA fragmentation, $10 \mu \mathrm{g}$ of each DNA sample was electrophoretically fractionated on $1.5 \%$ agarose gel with $0.5 \mu \mathrm{g} / \mathrm{ml}$ ethidium bromide. The DNA in the gel was visualized and photographed under UV light (Okamura et al., 2000).

\section{Statistical analysis}

Data were analyzed using one-way analysis of variance (ANOVA) followed by post-hoc analysis using SPSS. The data were expressed as mean \pm standard error (SE). Differences were considered statistically significant at $\mathrm{P}<0.05$.

\section{$\underline{\text { Results }}$}

Effect of I $\beta$-glucan on DEN induced inflammation

In the present study, plasma pro-inflammatory cytokines (IFN- $\gamma$, IL- 6 and TNF- $\alpha$ ) levels were increased significantly $(\mathrm{P}<0.05)$ in the DEN treated rats $(20 \mathrm{mg} / \mathrm{kg} \mathrm{b}$. wt.) compared to both the control and irradiated $\beta$-glucan group, as shown in Fig 1. However, administration of $\mathrm{I} \beta$-glucan attenuates toxicity effect of DEN in IFN- $\gamma$, IL6 and TNF $\alpha$ level in (DEN+ I $\beta$-glucan) group as compared to DEN group; I $\beta$-glucan alone did not change those cytokine levels significantly.

Effect of I $\beta$-glucan on DEN induced alteration in mitochondrial respiratory enzymes

As deduced from Fig. 2, DEN induced a significant reduction in mitochondria enzymes gene transcripts namely complex I and II concomitant with a significant elevation in mRNA of cytochrome $p_{450}$ gene expression compared to both the control and irradiated $\beta$-glucan group. While the administration of I $\beta$ - glucan alone or post DEN treatment showed a significant elevation in mitochondrial complex's (I, II) gene expressions compared to DEN group, but the level of cytochrome $p_{450}$ gene transcript significantly overexpressed in respect to DEN group.

\section{Effect of I $\beta$-glucan on DEN induced DNA fragmentation}

Agarose gel electrophoresis in Fig. 3 shows DNA fragmentation. Lane1: DNA marker with 100bp (M). Lane 4 shows apoptotic strand breaks/ streaking DNA in DEN group, while lane 2, 3 and 5 show intact undamaged DNA (control, glucan and $\mathrm{DEN}+\mathrm{I} \beta$-glucan) respectively. I $\beta$-glucan indeed reduced DEN induced DNA fragmentation.
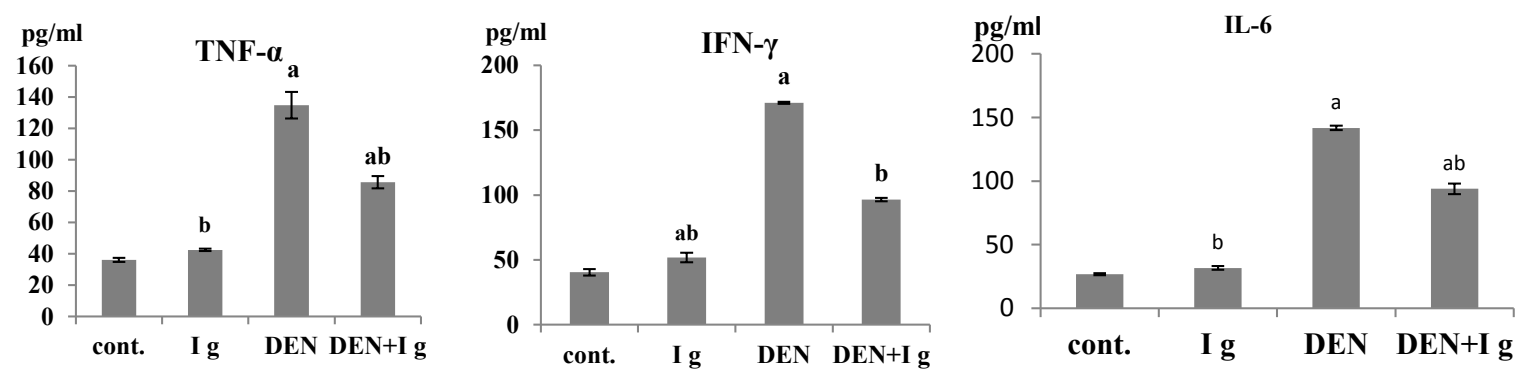

Fig. 1. Effect of I $\beta$-glucan on plasma inflammatory cytokines (IFN- $\gamma$, IL6 and TNF- $\alpha$ ), a= significantly different from control group, $b=$ significantly different from DEN group. Control (Cont.) group; I $\beta$-glucan administrated group (Ig); DEN administrated group; group administrated with DEN and I $\beta$-glucan (DEN+ Ig). 


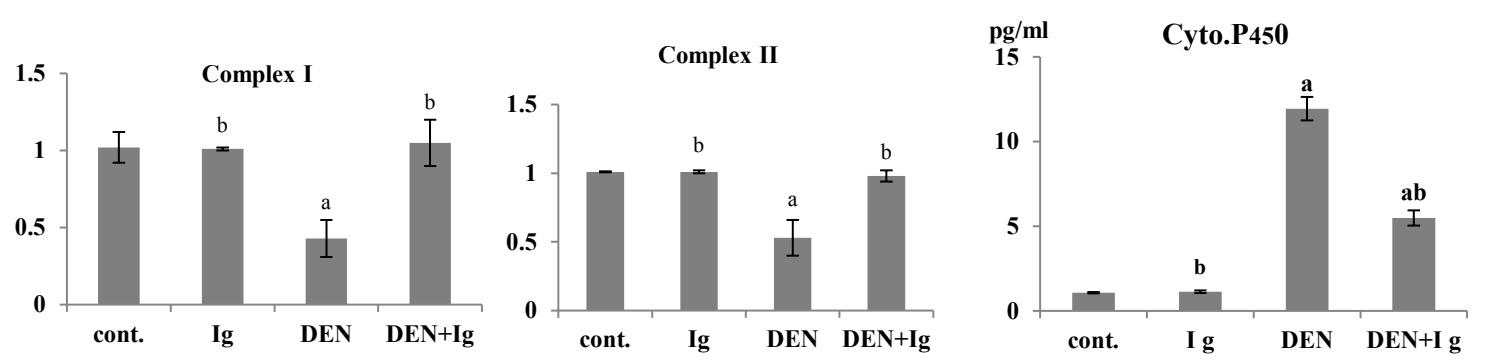

Fig. 2. Effect of I 1 -glucan on mitochondrial enzymes, $a=$ significantly different from control group, $b=$ significantly different from DEN group. Control (Cont.) group; I $\beta$-glucan administrated group (Ig); DEN administrated group; group administrated with DEN and I $\beta$-glucan (DEN+ Ig)

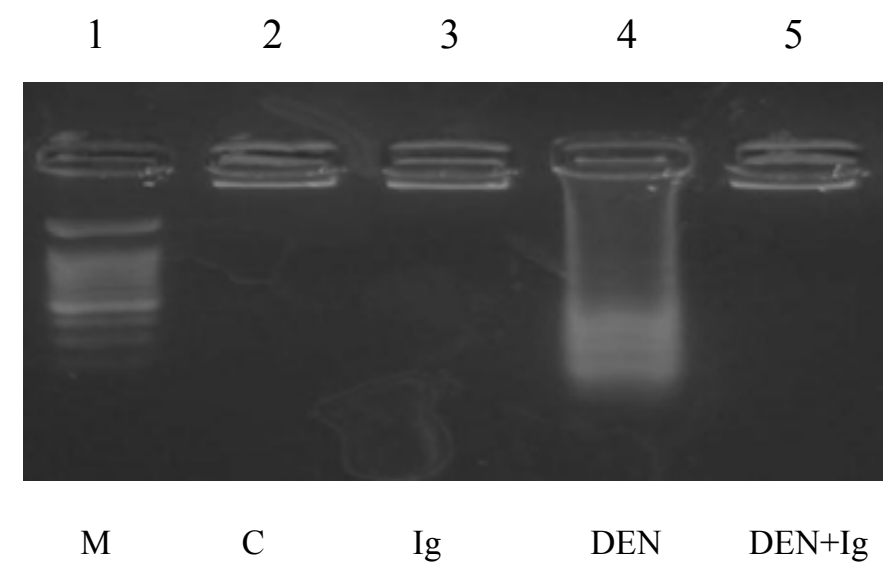

Fig. 3. Effect of I $\beta$-glucan on DNA fragmentation.

Effect of IB-glucan on DEN- induced kidney dysfunction

Figure 4 shows the status of urea and creatinine levels in the control and all groups. DEN induced a renal toxicity as shown in a 2 fold increase in the urea and creatinine levels as compared to control group. This increase of urea and creatinine levels due to DEN challenge was significantly decreased on post treatment with $\mathrm{I} \beta$-glucan for 4 weeks.

\section{Discussion}

In the current study, the proinflammatory cytokines; IFN- $\gamma$, TNF- $\alpha$, IL-6 revealed high levels in the DEN-administered group, which coincide with Horras et al. (2011). Toxicant generated inflammatory mediators, which stimulate the migration, infiltration of leukocytes and aggravates the primary injury. On the other hand, the oral administration of I $\beta$-glucan alleviates the alteration in plasma levels of IFN- $\gamma$, TNF- $\alpha$ and IL-6. It was found that I $\beta$-glucan enhanced the immuno- modulators, which might be may be ascribed to the effect of its constituents that are able to scavenge free radicals (Azab \& El-Dawi, 2005; Silva et al., 2015 and Silva et al., 2017). Additionally, Pillai et al. (2013) have demonstrated that $\beta$-glucan promote the repair of DNA of human lymphocytes and restored the TNF- $\alpha$ generation (Gao et al., 2003).

The major source of ROS and oxidative damage is the mitochondria (Fatemeh \& Jalal, 2013). The generation ROS is associated with several procedures such as autophagy, differentiation, metabolic adaption and immune cell activation (Sena \& Chandel, 2012). Jin et al. (2014) revealed that the basic neonatal genetic program; mitochondrial complex I is essential for the postnatal metabolic adaptation to counteract inflammation. In the current investigation, the dysfunction in the expression of respiratory chain enzymes complexes; complex I and II was observed in DEN treated group which might increase the levels of ROS. These respiratory deficiencies could be attributed to the impairment of metabolic pathways upstream to the oxidative phosphorylation, such as the different membrane transport systems. 

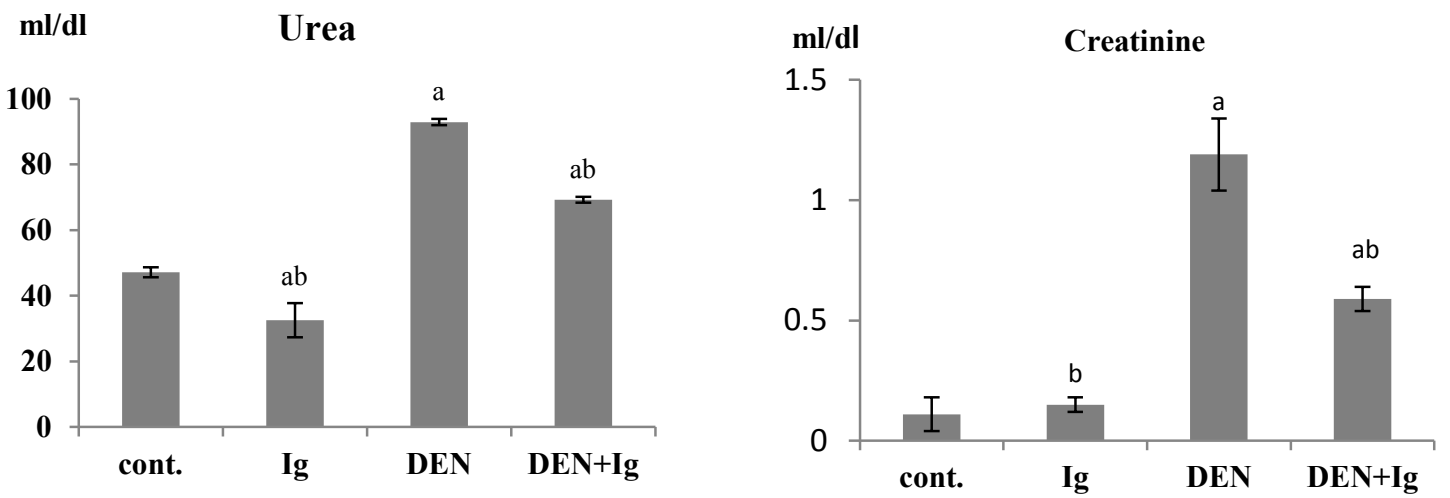

Fig. 4. Effect of I $\beta$-glucan on plasma urea and creatinine; $a=$ significantly different from control group, $b=$ significantly different from DEN group [Control: (Cont.) group, I $\beta$-glucan administrated group: (Ig), DEN administrated group: group administrated with DEN and I $\beta$-glucan (DEN+ Ig)].

Moreover, it was recorded that the administration of DEN induces increment in the expression of CYP $2 E_{1}$ mitochondrial which prompts ROS production, oxidative stress, and mitochondrial DNA damage that leads to cell damage ${ }^{34}$. This is in agreement with the results of the current study which may be attributed to the contribution of CYP2E1 in the DEN metabolism (Bansal et al., 2010). The activation of DEN by cytochrome $\mathrm{P}_{450}$ enzymes family generates free radicals (Briede et al., 2004). In the current study, administration of I $\beta$-glucan significantly suppress the over expression of CYP2E1 which could be supported by the contribution of receptors on the cell membrane that activate signaling pathways and transcriptional factors (Angeli et al., 2006; Hashimoto et al., 2002 and Okamoto et al., 2004). Therefore, the protective effect of $\beta$-glucan could be explained by its inhibitory effect on the CYP2E1.

As a consequence of DEN- generated ROS, the present study found that DEN administration significantly induced a renal injury which was evident by the increased concentration of markers related to the kidney function such as creatinine and urea. These findings are in agreement with the studies of Atakisi et al. (2013) and Pashmforoosh et al. (2015). The sharp increase in urea and creatinine levels have also been ascribed to the highly reactive free radicals produced by DEN, which initiates lipid peroxidation of the cell and endoplasmic reticulum membranes (Khan et al., 2001 and Vitaglione et al., 2004).

However, the treatment of I $\beta$-glucan markedly diminished the levels of urea and creatinine as shown in the results of the present study. The nephronprotective effects of I $\beta$-glucan may be attributed to its immunomodulatory effects. Therefore, the protective effect of I $\beta$-glucan against DEN toxicity could be attributed to their antioxidant and anti-inflammatory efficacy, especially $\beta$-glucan, which had low molecular weight, high solubility and low viscosity (Byun et al., 2016).

\section{Conclusion}

In conclusion, I $\beta$ glucan, seemed to attenuate the cytotoxic effect DEN by its immunomodulatory effect associated with its free radical scavenging activities. Moreover, the I $\beta$-glucan prevented mitochondrial disruption. Further studies are underway to elucidate the molecular mechanisms involved in I $\beta$-glucan protection .

\section{References}

Akramienė, D., Kondrotas, A., Didžiapetrienè, J. and Kèvelaitis, E. (2007) Effects of b-glucans on the immune system. Medicina (Kaunas), 43, 597-606.

Andersson, S.C., Zomorodipour, A., Jan Andersson, O., Sicheritz-Ponte, T., Cecilia, U., Alsmark, M., Podowski, R.M., Kristina, A., NaÈslund, A., Winkler, H.H. and Kurland, C.G. (1998) The genome sequence of Rickettsia prowazekii and the origin of mitochondria . Nature, 396, 133-140.

Angeli, J.P., Ribeiro, L.R., Gonzaga, M.L., Soares Sde, A., Ricardo, M.P., Tsuboy, M.S., Stid, R., 
Knasmueller, S., Linhares, R.E. and Mantovani, M.S. (2006) Protective effects of $\beta$-glucan extracted from Agaricus brasiliensis against chemically induced DNA damage in human lymphocytes. Cell Biol Toxicol. 22, 285-291.

Atakisi, O., Atakisi, E., Ozcan, A., Karapehlivan, M. and Kart, A. (2013) Protective effect of omega-3 fatty acids on diethyl nitrosamine toxicity in rats. Eur. Rev. Med. Pharmacol. Sci. 17, 467-71.

Azab, K. and El-Dawi, H.A. (2005) The modifying effect of beta 1,3-D-glucan on gamma radiation induced oxidative stress and genotoxicity in male mice. Egypt. J. Rad. Sci. Applic. 18, 39-52.

Bansal, A.K., Trivedi, R., Soni, G.L. and Bhatnagar, D., (2000) Hepatic and renal oxidative stress in acute toxicity of Nnitrosodiethylamine. Indian J. Exp. Boil. 38(9), 916-920.

Bansal, S., Liu, C.P. and Sepuri, N.B. (2010) $\begin{array}{llll}\text { Mitochondria-targeted cytochrome } & \mathrm{P} 450 & 2 \mathrm{E} 1\end{array}$ induces oxidative damage and augments alcoholmediated oxidative stress. J. Biol. Chem. 285, 24609-24619.

Briede, J.J., Godschalk, R.W., Emans, M.T., De Kok, T.M., Van, A.E., Van, M.J., Van Schooten, F.J. and Kleinjans, J.C. (2004) In vitro and in vivo studies on oxygen free radical and DNA adduct formation in rat lung and liver during benzo[a]pyrene metabolism. Free Radic. Res. 38, 995-1002.

Byun, E.B., Park, S.H., Jang, B.S., Sung, N.Y. and Byun, E.H. (2016) Gamma-irradiated $\beta$-glucaninduces immunomodulation and anticancer activity through MAPK and NF- $k$ B pathways. J. Sci. Food Agric. 96, 695-702.

Cho, M., Kim, B.Y. and Rhim, J.H. (2003) Degradation of alginate solution and powder by gamma irradiation. Food Eng. Prog. 7, 141-145.

El-Sonbaty, S.M., Ismail, M.F.A. and Nabeel, A. (2013) Irradiated $\beta$-glucan enhances immune response to bacterial infection through CD4 and CD8 T-lymphocytes. Int. J. Radiat. Res. 11, 35-42.

Ezz, M.K., Elsonbaty, S.M., Abdelgawad, S.M. and Moawed, F.S.M. (2017) Modulatory effect of B- glucans aginst nitrosodiethylamine-induced hepatocarcinogenesis in rats by suppressing NFKb/IL-6. Signaling, 8(2), 2528-2537.
Farombi, E.O., Shrotriya, S. and Surh Kolaviron, Y.J. (2009) inhibits dimethyl nitrosamine induced liver injury by suppressing COX-2 and iNOS expression via NF-kappaB and AP-1. Life Sci. 84, 149-55.

Fatemeh, S. and Jalal, P. (2013) Mitochondrial toxicity of depleted uranium: protection by beta-glucan. Iranian Journal of Pharmaceutical Research, 12, 131-140.

Fulda, S., Galluzzi, L. and Kroemer, G. (2010) Targeting mitochondria for cancer therapy. Nat. Rev. Drug Discov. 9, 447-64.

Gao, J., Opiteck, G.J., Friedrichs, M.S., Dongre, A.R. and Hefta, S.A. (2003) Changes in the protein expression of yeast as a function of carbon source. J. Proteome. Res. 2, 643-649.

Hashimoto, T., Nonaka, Y. and Minato, K. (2002) Suppressive effect of polysaccharides from the edible and medicinal mushrooms, Lentinus edodes and Agaricus blazei, on the expression of cytochrome P450s in mice. Biosci Biotechnol. Biochem. 344, 610-614.

Horras, C.J., Lamb, C.L. and Mitchell, K.A. (2011) Regulation of Hepatocyte Fate by Interferon- $\gamma$. Cytokine Growth Factor Rev. 22(1), 35-43.

Hunter, K.W. Jr., Gault, R.A. and Berner, M.D. (2002) Preparation of microparticulate b-glucan from Saccharomyces cerevisiae for use in immune potentiation. Lett. Appl. Microbiol. 35, 267.

Jaehrig, S.C., Rohn, S., Kroh, L.W., Fleischer L.G. and Kurz, T. (2007) In-vitro potential antioxidant activity of (1-->3), (1-->6)-beta-D-glucan and protein fractions from Saccharomyces cerevisiae cell walls. J. Agric. Food Chem. 55, 4710-4716.

Jakszyn, P. and Gonzalez, C.A. (2006) Nitrosamine and related food intake and gastric and esophageal cancer risk: a systematic review of the epidemiological evidence. World J. Gastroenterol. 12, 4296-4303.

Jin, Z., Wei, W., Yang, M., Du, Y. and Wan, Y. (2014) Mitochondrial complex I activity suppresses inflammation and enhances bone resorption by shifting macrophage osteoclast polarization. Cell Metabolism. 20, 483-498.

Khan, N., Sharma, S., Alam, A., Saleem, M. and 
Sultana, S. (2001) Tephrosia purpurea ameliorates $\mathrm{N}$-diethylnitrosamine and potassium bromatemediated renal oxidative stress and toxicity in Wistar rats. Pharmacol Toxicol. 88, 294-299.

Kushnareva, Y., Murphy, A.N. and Andreyev, A. (2002) Complex I-mediated reactive oxygen species generation: modulation by cytochrome $\mathrm{c}$ and NAD (P) + oxidation-reduction state. Biochem. J. 368, 545-553.

Magda, K., Elsonbaty S.M., Abdelgawad, S.M. and Moawed, F.S. (2017) Modulatory effect of B-glucans aginst nitrosodiethylamine-induced hepatocarcinogenesis in rats by suppressing NFKb/IL-6 Signaling. RJPBCS, 8(2), 2528-37.

Okamura, T., Miura, T., Takemura, G., Fujiwara, H., Iwamoto, H., Kawamura, S., Kimura, M., Ikeda, Y., Iwatate, M. and Matsuzaki, M. (2000) Effect of caspase inhibitors on myocardial infarct size and myocyte DNA fragmentation in the ischemiareperfused rat heart. Cardiovascular Research, 45(3), 642-50.

Okamoto, T., Kodoi, R. and Nonaka, Y. (2004) Lentinan from shiitake mushroom (Lentinus edodes) suppresses expression of cytochrome P450 1A subfamily in the mouse liver. Biofactors, 21, 407-374.

Pashmforoosh, M., Rezaie, A., Karamallah, M.H., Fazlara, A., Shahriari, A. and Najafzadeh, H. (2015) Effects of caffeine on renal toxicity induced by diethylnitrosamine. Zahedan J. Res. Med. Sci. 17, 7-9.

Perfeito, R., Cunha-Oliveira, T. and Rego, A.C. (2012) Revisiting oxidative stress and mitochondrial dysfunction in the pathogenesis of Parkinson disease-resemblance to the effect of amphetamine drugs of abuse. Free Radic Biol Med. 53, 17911806.

Pillai, T.G. and Uma, Devi, P. (2013) Mushroom beta glucan: potential candidate for post irradiation protection. Mutation Research, 751, 109-115.

Pradeep, K., Mohan, C.V., Gobianand, K. and Karthikeyan, S. (2007) Silymarin modulates the oxidant antioxidant imbalance during diethylnitrosamine induced oxidative stress in rats. Eur. J. Pharmacol. 560, 110-6.
Ruthes, A.C., Carbonero, E.R., Córdova, M.M., Baggio, C.H., Santos, A.R., Sassaki, G.L., Cipriani, T.R., Gorin, P.A. and Iacomini, M. (2013) Lactarius rufus $(1 \rightarrow 3), \quad(1 \rightarrow 6)-\beta$-D-glucans: $\quad$ structure, antinociceptive and anti-inflammatory effects. Carbohydr. Polym. 94, 129-316.

Sena, L.A. and Chandel, N.S. (2012) Physiological roles of mitochondrial reactive oxygen species. Mol. Cell. 48, 158-167.

Sener, G., Toklu, H., Ercan, F. and Erkanli, G. (2005) Protective effect of $b$-glucan against oxidative organ injury in a rat model of sepsis. Int. Immunopharm. 5, 1387-96.

Shoffiner, J.M. and Wallace, D.C (1995) In: "Metabolic and Molecular Basis of Inherited Disease", C.R. Scriver, A.L., Beaudet, W.S. Sly, D. Valle (Ed.), pp.1535-1609. Mctraw-Hill, New York.

Silva, V.D.O., Lobato, R.V. and Andrade, E.F. et al (2015) $\beta$-Glucans (Saccharomyces cereviseae) Reduce glucose levels and attenuate alveolar bone loss in diabetic rats with periodontal disease. PLoS One, 10, e0134742.

Silva, Vd., de Moura, N.O. and Rodrigues de Oliveira, L.J., et al. (2017) Promising effects of beta glucans on metabolism and on the immune responses: review article. American Journal of Immunology, 13, 62-72.

Silveira, M.L., Smiderle, F.R., Moraes, C.P., Borato, D.G, Baggio, C.H., Ruthes, A.C., Wisbeck, E., Sassaki, G.L., Cipriani, T.R., Furlan, S.A. and Iacomini, M. (2014) Structural characterization and anti-inflammatory activity of a linear $\beta$-D-glucan isolated from Pleurotus sajorcaju. Carbohydr. Polym. 113, 588-596.

Sima, P., Vannucci, L. and Vetvicka, V. (2018) $\beta$-glucans and cholesterol (Review). Int. J. Mol. Med. 41(4), 1799-1808.

Smeekens, S.P., Gresnigt, M.S., Becker, K.L., Cheng, S.C.., Netea, S.A., Jacobs, L., Jansen, T., van de Veerdonk, F.L., Williams, D.L., Joosten, L.A., Dinarello, C.A. and Netea, M.G. (2015) An antiinflammatory property of Candida albicans $\beta$-glucan: Induction of high levels of interleukin-1 receptor antagonist via a Dectin-1/CR3 independent mechanism. Cytokine, 71(2), 215-22. 
Sui, Y., Potula, R., Dhillon, N., Pinson, D., Li, S., Nath, A., Anderson, C., Turchan, J., Kolson, D., Narayan, O. and Buch, S. (2004) Neutonal apoptosis is mediated by CXCL10 overexpression In simian human immunodeficiency virus encephalitis. Am. J. Pathol. 164, 1557-1566.

Verna, L., Whysner, J. and Williams, G.M. (1996) $\mathrm{N}$-nitrosodiethylamine mechanistic data and risk assessment: bioactivation, DNA-adduct formation, mutagenicity, and tumor initiation. Pharmacol. Ther. 71, 57-81.

Vetvicka, V. (2011) Glucan-immunostimulant, adjuvant, potential drug. World. J. Clin. Oncol. 2, 115-119.

Vitaglione, P., Morisco, F. and Caporaso, N. et al. (2004) Dietary antioxidant compounds and liver health. Crit Rev Food Sic Nutr. 44(7-8), 575-86.
Vos, A.P., M'Rabet, L., Stahl, B., Boehm, G. and Garssen, J. (2007) Immune-modulatory effects and potential working mechanisms of orally applied nondigestible carbohydrates. Crit. Ver. Immunol. 27, 97-140.

Zeković, D.B., Kwiatkowski, S., Vrvić, M.M., Jakovljević, D.and Moran, C.A. (2005) Natural and modified $(1 \rightarrow 3)-\beta$-D-glucans in health promotion and disease alleviation. Crit. Rev. Biotechnol. 25, 205-230.

\section{التأثير المناعي لجزيء البيتا الجلوكان المُشعع ضد السمية الكلوية المستحثة بداي-إثيل} نيتروزامين

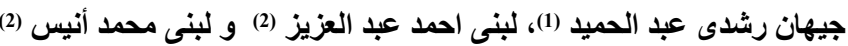

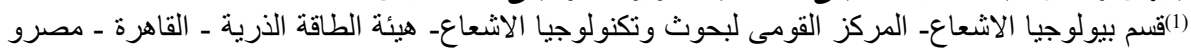

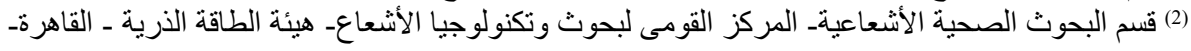

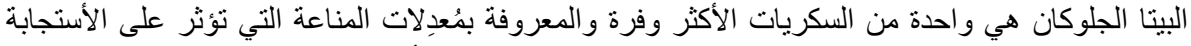

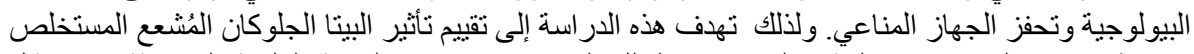

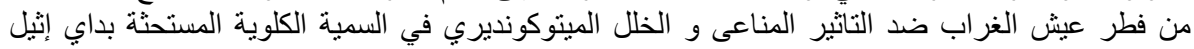

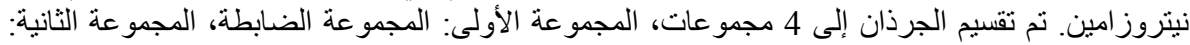

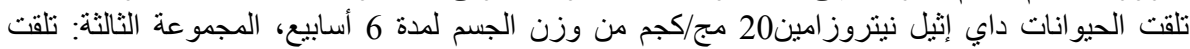

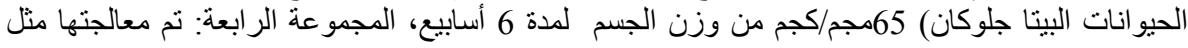

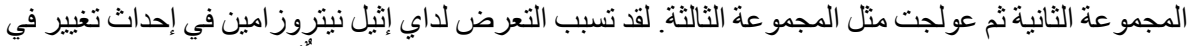

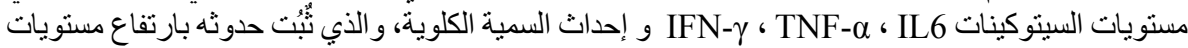

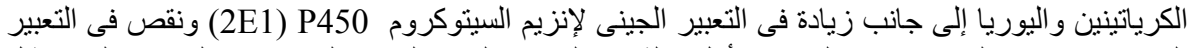

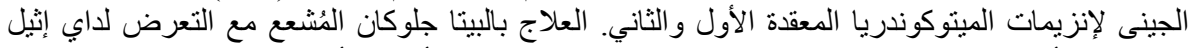

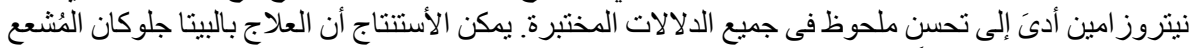

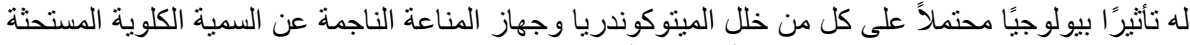

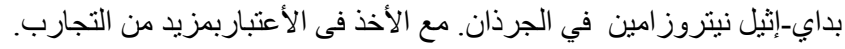

